\title{
39. SEISMIC FACIES AND STRUCTURAL FRAMEWORK OF THE SOUTHERN MEXICO CONTINENTAL MARGIN1
}

\author{
Thomas H. Shipley, Scripps Institution of Oceanography, University of California at San Diego, La Jolla, California
}

\begin{abstract}
Combination of DSDP Leg 66 drilling results with a seismic facies analysis provides a basis for interpreting the regional sedimentation and environmental factors on the Mexican continental margin. The spatial relationship between the six recognized seismic facies and their variations distant from the actual drill holes also facilitates interpretation of tectonic and sedimentologic processes responsible for generation of the continental slope. Base of slope structures observed in the vicinity of a large submarine canyon are evidence for accretion of trench turbidites into the lower slope with significant deformation and rotation to high angles within $4 \mathrm{~km}$ of the trench axis. Where turbidites are not present in the trench axis, oceanic sediments continue beneath the slope, suggesting little or no addition (accretion) of material at the base of slope. Turbidites have been absent for long periods of time from most of the trench. Because Leg 66 drilling was concentrated near a major canyon that has been supplying turbidites to the trench since the late Miocene, slope generation is interpreted as the result of addition of trench deposits to the lower slope. Since the cross-sectional area is similar among areas with and without trench turbidites, other processes may be responsible for adding sediments to the accretionary zone. One such process may be the incorporation of slope deposits by incipient deformation, which is observed in some of the drill sites. The regional uplift may result from material added to the margin by accretion at deeper structural levels.
\end{abstract}

\section{INTRODUCTION}

Understanding of tectonic processes along convergent continental margins has come mainly from the observation of structures on widely spaced transects and rarely from more complete surveys. Even though the relative importance of regional versus local structural styles is not well known, study of transects has led to the development of a number of tectonic models and identification of tectonic provinces (Hussong et al., 1976; Karig and Sharman, 1975; Kulm and Fowler, 1974; Moore and Karig, 1976; Scholl et al., 1970; Seely et al., 1974; von Huene, 1979; and others).

The Mexico margin is recognized as a possible end member in convergent margins (Karig, 1974) with a narrow transition zone between oceanic and continental crust, absence of a significant forearc sedimentary basin, and a narrow accretionary zone. One significant result of recent geophysical work off Mexico was the discovery of recently active accretionary processes (Karig et al., 1978; Shipley et al., 1980). Drilling on Leg 66 refined the Seely et al. (1974) and Karig and Sharman (1975) models of slope generation. Landward-dipping reflections were found to correlate in a general way with the interbedded sands and mudstones and were interpreted to have been accreted to the slope from the trench axis or lower slope.

The purpose of the present report is to review geophysical data from this area in order to bring the drilling results into regional perspective with relation to other structures along the margin. Drill sites were optimally located to test certain hypotheses and constrained by engineering and safety aspects. I want to emphasize that

\footnotetext{
${ }^{1}$ Initial Reports of the Deep Sea Drilling Project, Volume 66.
}

even in the small area surveyed $(200 \mathrm{~km} \times 100 \mathrm{~km})$, there are many structural variations that are less indicative of significantly different tectonic processes than of varying sedimentation factors (Fig. 1). A number of seismic facies provide information about lateral sedimentologic variations distant from the drill sites.

The Middle America Trench is a shallow depression along the continental border of Central America and Mexico (Fisher, 1961, 1974). The trench and associated structures are subdivided into two distinct provinces at the Gulf of Tehuantepec. Southward, active volcanoes appear parallel to and separated from the trench by a large sedimentary basin (Fisher, 1961; Ross and Shor, 1965; Seely et al., 1974; Shipley et al., in press). Northward, the volcanics are far inland and diverge from the present trench trend; the distance from the trench to the shoreline is narrow; and continental basement rocks as old as Precambrian and as young as Cretaceous are exposed at the shoreline (de Czerna, 1971; Guzman, 1950; Kesler, 1973). The Mexico margin was truncated prior to the late Miocene, juxtaposing Cretaceous batholith rocks and a young accretionary zone of post-middle Miocene age. The timing and method of truncation were in part the objectives of Leg 66 drilling. Recent studies of this portion of the margin (Karig et al., 1978; McMillen et al., in press; Shipley et al., 1980; Underwood and Karig, 1980) have aptly described the basic structural and sedimentological regime. These studies show obvious deformation at the base of the slope, minor slope basins, and ridges and landward-dipping reflectors within the slope section characteristic of accretion.

\section{SEISMIC FACIES ANALYSIS}

In order to extrapolate the drilling results to the regional geology and to understand the structural variations of the margin, we consider Leg 66 drill sites within 


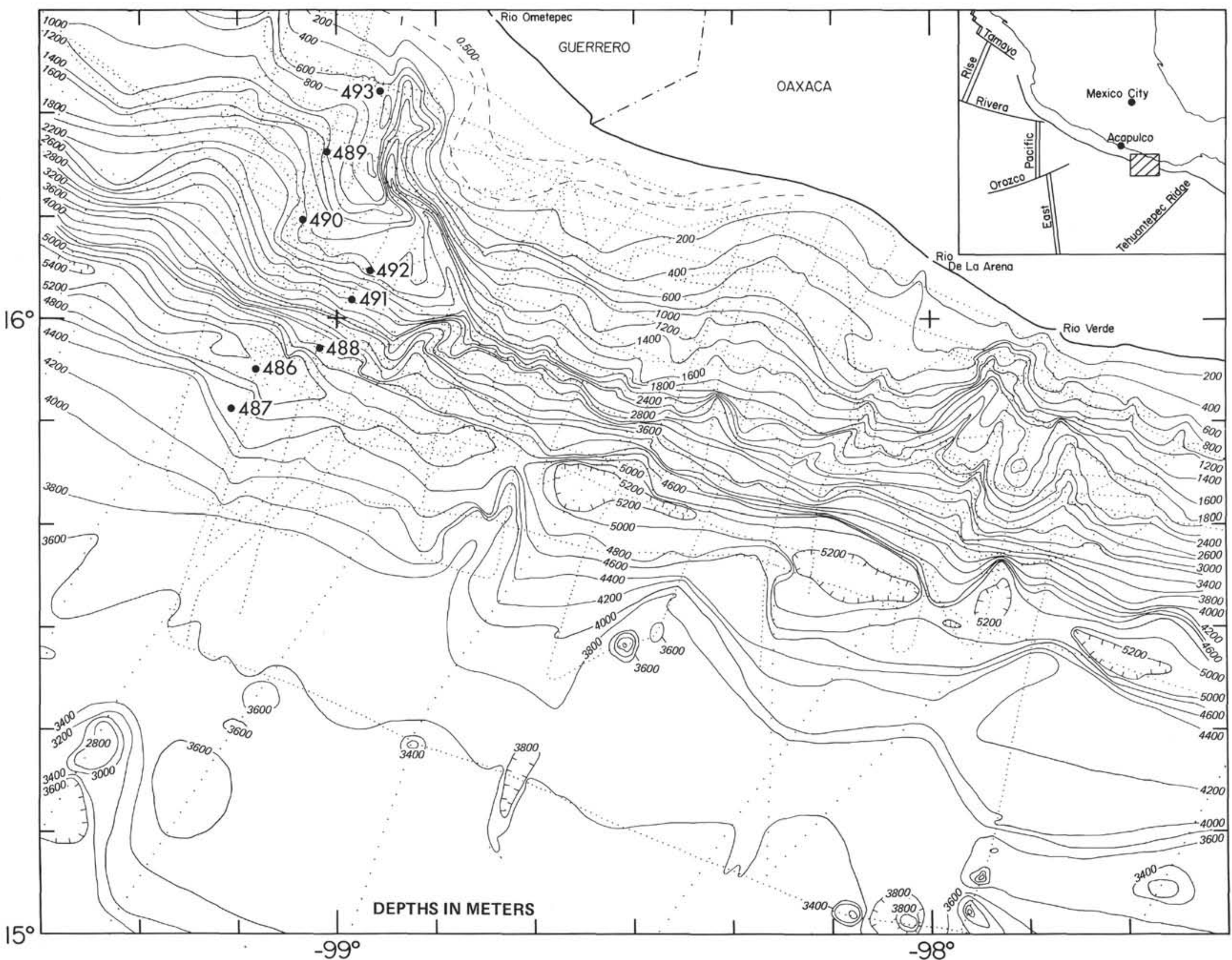

Figure 1. Bathymetric chart of the continental margin of Mexico. Dotted lines are ship tracks (widely spaced dots Vema 28 and Vema 32 cruises of Lamont-Doherty Geological Observatory; others by University of Texas). Contoured in corrected meters, 200-meter contour interval. 
a regional seismic facies framework. When we examine reflection continuity, geometry, amplitude, frequency, interval velocity, and external shape of seismic reflection data, we can develop seismic facies models (Mitchum et al., 1977), which Sangree and Widmier (1977) have used to define seismic facies in clastic environments. The seismic facies can then be related to the depositional and environmental facies of the sediments. We have used this approach in the analysis of the sedimentary regime of the Mexico continental margin.

Six seismic facies have been identified on the margin between the outer rise and upper slope (Fig. 2). One is defined on the outer rise, one in the trench, two on the lower slope, and two on the upper slope. These facies overlap in space and time (Fig. 3). Some of these intervals correlate well with the sampled lithofacies, but some differ more seismically than can be accounted for in the drilling data. The inability to differentiate the lithofacies may be related to the dominance of finegrained sedimentary components deposited by a variety of processes and the power of seismic facies analysis in separating various depositional processes.

\section{Sheet Drape (outer rise)}

The outer rise is characterized by a thin (170-m) seismically defined sedimentary interval overlying oceanic crustal rocks (Figs. 4-9; Figs. 5-9 appear in the back pocket of this volume). The section thickens slightly in graben-like structures and thins on slopes produced by normal down-to-the-trench step faults. The general external form of the unit is a conformable sheet. Internally, reflections are low amplitude or generally absent except for a single moderate-amplitude and coherent reflection in about the middle of the section (Fig. 8). The base of the interval is a high-amplitude rather continuous reflection except where offset by faulting. This reflection is smoother and more coherent than is normally associated with the top of the oceanic crust. This suggests a thin section of more highly reflective sediments capping the rough basement topography. The complete section has a velocity of about $1.7 \mathrm{~km} / \mathrm{s}$ (from reflection velocity analysis).

This interval is the sheet-drape seismic facies of Sangree and Widmier (1977), which they interpret as deep marine hemipelagic clays and oozes deposited on the basin floor. Site 487 recovered hemipelagic muds with fine sand and silt layers overlying pelagic clays deposited on pre-late Miocene oceanic crust. The pelagic clays were deposited in the open ocean below the calcium carbonate compensation depth, and hemipelagics deposited as the crust neared the continental margin. As Scholl et al. (1970) and Piper (1973) have shown, even with an intervening trench between the continental margin source and the ocean basin, significant terrigenous fine-grained sediments (silt and clay) do bypass the trench with sediments deposited as distal turbidites or from a nepheloid layer. Transportation of fine silt and clay great distances near bottom has been documented in many abyssal plain settings. In some cases, turbidity currents have been found to deposit sediments in an upslope direction, either because of the momentum of flow or because of great thickness of distal tur- bidite flows (Damuth and Embley, 1979; Shipley, 1978). The preferential thinning on slopes and highs suggests minor redeposition of sediments by bottom currents or slope instability (slumping). The hemipelagic component is deposited in all the local environments of this margin. It cannot be identified seismically elsewhere, however, because it is swamped by coarse terrigenous detritus, whereas here the coarse detritus is trapped in the trench axis. These factors are important in correctly interpreting the inner slope sedimentation regime.

\section{Onlapping Fill (trench axis)}

The trench is a highly irregular bathymetric feature with significant variations in depth and width within the surveyed area. The axis often contains the sheet-drape facies overlain by a stratified onlapping fill facies up to 625 meters thick (Fig. 5). This facies is restricted to the northwestern and southeastern axial parts of the trench. The interval onlaps the sheet-drape facies in a seaward direction and the base of slope in a landward direction. The interval contains many nearly parallel, laterally coherent (for 5-10 km), moderate-to-variable amplitude reflections. In detail the reflections often extend only partway across the pond or contain buried channel features that may be related to axial transport of sediment by turbidity flows (McMillen et al., in press; McMillen and Haines, this volume).

An axial profile constructed from reflection profiles normal to the trench axis illustrates the interdependence of crustal morphology, submarine canyons, and depositional and tectonic processes (Fig. 10). Stratified sedimentary deposits occur only where submarine canyons associated with the Rio Ometepec and Rio Verde are incised into the upper slope and shelf and funnel large volumes of sediments to the trench floor. The onlapping fill facies does not extend northwest of the Line OM-2N crossing because of a high in the oceanic crust. Sediments are slowly filling to the southeast of the Rio Ometepec as sediment supply-convergence rates allow, though a sill may also be present near Line OM-5N. Our survey data base is not dense enough for us to differentiate between isolated ponds and a continuous smooth axial gradient between the crossings where the onlapping fill facies is present. However, the average longitudinal slope is less than one degree between the deepest portion of the trench on adjacent crossings that contain sediment fill. The location of the deepest part of the trench varies on crossings between the base of the inner slope to the base of the outer slope. The bathymetric axis seems independent of the sediment fill but is at least partly influenced by folding and faulting within the onlapping fill. Because of the near-uniformity of longitudinal axial gradients derived from crossing normal to the axis, it appears that between Lines OM-5N and MX-14 (Fig. 10), where there is a significant sediment supply, isolated ponds are not formed. Apparent depth variations in ponds noted on reflection profiles aboard the Glomar Challenger (Fig. 11) result from a track which is not along the true axis but on various faulted and raised sections of turbidite fill instead. Thus the present variation in depth of these ponds is the result of postdepositional processes. 


\begin{tabular}{|c|c|c|c|c|c|c|c|}
\hline Seismic Facies & $\begin{array}{l}\text { Site/Interval } \\
(\mathrm{m})\end{array}$ & Lithology & Bedding Dips & Age & $\begin{array}{c}\text { Sedimentation } \\
\text { Rate } \\
(\mathrm{m} / \mathrm{m} \cdot \mathrm{y} .)\end{array}$ & Environment & Dominant Lithology \\
\hline sheet drape & $487,0-171$ & $\begin{array}{l}\text { muds and clay both with } \\
\text { ash layers }\end{array}$ & horizontal & $\begin{array}{l}\text { Quaternary to } \\
\text { late Miocene }\end{array}$ & $7-126$ & $\begin{array}{l}\text { hemipelagic and pelagic } \\
\text { open ocean basin, } \\
\text { low energy }\end{array}$ & same as sampled \\
\hline onlapping fill & $486,0-38$ & $\begin{array}{l}\text { muddy sands and fine to } \\
\text { medium coarse sands } \\
\text { with minor clay and mud }\end{array}$ & not observed & Quaternary & very high & $\begin{array}{l}\text { basinal turbidites and } \\
\text { hemipelagic component, } \\
\text { moderate energy }\end{array}$ & $\begin{array}{l}\text { sand-prone near submarine } \\
\text { canyons becoming more mud- } \\
\text { prone at distal localities- } \\
\text { facies absent over most of } \\
\text { survey area }\end{array}$ \\
\hline chaotic fill & $\begin{array}{l}488,0-313 \\
490,475-595 \\
\\
491,67-456 \\
492,0-247\end{array}$ & $\begin{array}{l}\text { muddy silt and mud with } \\
\text { minor to rare ash and } \\
\text { thin, fine to medium } \\
\text { sand layers, calcareous } \\
\text { concentrations }\end{array}$ & $\begin{array}{l}\text { low to steep } \\
\text { WNW, moderate } \\
\text { NNE, low to steep } \\
\text { SE, low to steep }\end{array}$ & $\begin{array}{l}\text { Quaternary to } \\
\text { late Miocene }\end{array}$ & $\begin{array}{c}490-610 \\
438 \\
213-2765 \\
11-133\end{array}$ & $\begin{array}{l}\text { hemipelagic slope sediments } \\
\text { redeposited by slumping and } \\
\text { sliding with occasional } \\
\text { overbank or interchannel } \\
\text { deposition, moderate energy }\end{array}$ & same as sampled \\
\hline $\begin{array}{l}\text { moderate } \\
\text { amplitude and } \\
\text { continuity }\end{array}$ & $\begin{array}{l}488,313-428 \\
491,456-542 \\
492,247-290\end{array}$ & $\begin{array}{l}\text { fine-to-coarse pebbly } \\
\text { sand interbedded with } \\
\text { muddy silt }\end{array}$ & $\begin{array}{l}\text { ENE, moderate } \\
\text { WNW to E, low } \\
\text { NW, moderate }\end{array}$ & $\begin{array}{l}\text { Quaternary to } \\
\text { late Miocene }\end{array}$ & $\begin{array}{c}510-620 \\
1490-5333 \\
96-133\end{array}$ & $\begin{array}{l}\text { basinal(?) turbidites with } \\
\text { interbedded hemipelagic } \\
\text { components, moderate } \\
\text { energy }\end{array}$ & $\begin{array}{l}\text { sand-prone only near submarine } \\
\text { canyons, otherwise same lithology } \\
\text { as chaotic fill facies }\end{array}$ \\
\hline $\begin{array}{l}\text { slope front } \\
\text { fill }\end{array}$ & $\begin{array}{l}489,0-302 \\
490,2-475 \\
493,0-203\end{array}$ & $\begin{array}{l}\text { muddy silt and mud often } \\
\text { laminated and bioturbated } \\
\text { with common ash and } \\
\text { fine sand layers, and rare } \\
\text { woody debris, shell } \\
\text { fragments, and limestone }\end{array}$ & $\begin{array}{l}\text { low to steep } \\
\text { low } \\
\text { low to moderate }\end{array}$ & $\begin{array}{l}\text { Quaternary to } \\
\text { early Miocene }\end{array}$ & $\begin{array}{l}13-221 \\
42-600 \\
11-52\end{array}$ & $\begin{array}{l}\text { upper slope hemipelagic and } \\
\text { sheet deposits, moderate } \\
\text { energy }\end{array}$ & same as sampled \\
\hline progradational & $493,203-652$ & $\begin{array}{l}\text { muddy silt and mud with } \\
\text { thin ash beds and cal- } \\
\text { careous layers and con- } \\
\text { cretions, sand and sand } \\
\text { layers increase below } \\
400 \mathrm{~m}\end{array}$ & $\begin{array}{l}\text { variable direction } \\
\text { to south in lower } \\
\text { part, low to mod- } \\
\text { erate dip }\end{array}$ & Miocene & $23-139$ & $\begin{array}{l}\text { upper slope hemipelagic } \\
\text { prograding into deeper water } \\
\text { with significant wave-base } \\
\text { contributions, moderate to } \\
\text { high energy }\end{array}$ & $\begin{array}{l}\text { same as sampled, highly restricted } \\
\text { facies }\end{array}$ \\
\hline
\end{tabular}

Figure 2. Characteristics of the six seismic facies. (Uncompacted sedimentation rates for Sites 488-493 from Shepard and McMillen, this volume.) 


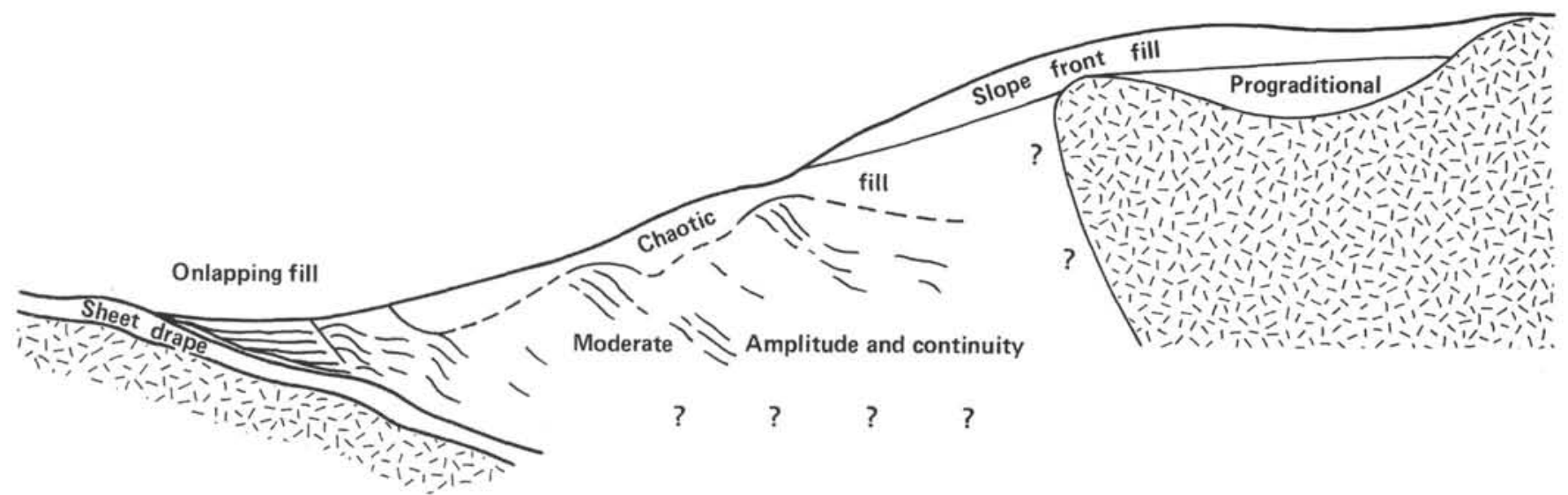

Figure 3. Schematic seismic facies section showing spatial interrelation of facies.

According to Sangree and Widmier (1977), this onlapping fill facies on the basin floor is deposited from low-velocity turbidity currents. This is consistent with cores from Site 486 and piston cores (McMillen et al., in press; McMillen and Haines, this volume), which recovered interbedded but poorly sorted sands and muds. It is also evident that significant longitudinal flow must distribute the sediments along the axis. Further, the facies probably is most sand-prone near the submarine canyons, becoming more mud- and silt-prone farther from these limited point sources. Site 486 was located to sample a sand-prone area, but even coarser sediments probably occur nearer the Ometepec Canyon. Piston cores show a distinct fining away from the canyon (McMillen and Haines, this volume).

\section{Chaotic Fill (slope)}

Much of the lower and middle slope region is covered with a variable thickness $(0-350 \mathrm{~m})$ of sediments with discontinuous and indistinct reflections. The thickness of the interval is independent of present slope gradient irregularities (Figs. 6, 7, and 12). It appears in places to extend down to the trench and upslope in places beneath the slope front fill facies. Internally, this interval is best defined by its numerous moderate amplitude reflections, which extend laterally only a kilometer or less.

This is the chaotic fill seismic facies of Sangree and Widmier (1977), defined as consisting of gravity-masstransported deposits. This facies was penetrated at Sites 488,491 , and 492 and consists of muds interbedded with occasional ash and fine sand layers. The chaotic nature of the reflections may be explained by a combination of slumps and slides of unstable hemipelagic muds deposited on the continental slope and also by deposition in small basins later disturbed by uplift and faulting. Penecontemporaneous lower slope sedimentation and deformation may have also occurred and account for part of the chaotic nature. Occasional fine sand intervals may record the passing of a large turbidity current or overbank flows. Source proximity and upper slope sediment transport downslope by slumping and sliding may explain the higher accumulation rates in these hemipelagic deposits than at Site 487 , on the ocean crust (Fig. 2).

\section{Moderate Amplitude and Continuity (slope)}

Landward-dipping reflections within the slope extending from the base of slope to the edge of the continent compose the moderate amplitude and continuity seismic facies (Figs. 6 and 7). The maximum thickness of this interval is unknown and has no characteristic external form. It is overlain in places by the chaotic fill and slope front fill seismic facies. Reflections are gently to steeply landward-dipping and of moderate amplitude. The reflections occur as groups of subparallel reflections, a few to tens of reflections wide, separated by zones of more incoherent reflections. These packages of reflections have lengths to perhaps $10 \mathrm{~km}$, though individual reflections are seldom longer than $3 \mathrm{~km}$. The lateral distribution of this facies is shown in Figure 13.

This seismic facies is not adequately classified by Sangree and Widmier (1977) because its form and present geometry are related to tectonic processes. Drilling has shown that this facies is composed of interbedded medium to coarse sands and muds (Fig. 2). The coarsegrained sediments must originate in the shelf zone. Deposition on the slope would have to be related to local slope basin filling or channel deposits. Perhaps these sediments were originally part of the onlapping fill trench axis facies which has been incorporated into the slope by faulting, rotation, and uplift. The lack of lateral continuity of individual reflections in comparison to the onlapping fill facies may be due to the fact that these sediments are more deeply buried, which effectively biases the recordings to lower frequency. Lower reflection continuity and divergence may be the result of significant deformation as these deposits are incorporated into the slope.

The more clearly defined groups of longer reflections are restricted to the upslope vicinity of the Ometepec Canyon, with only very short reflections observed in most other areas. This may indicate a lateral change in facies from a sand-prone zone where reflections are more numerous and longer to a more mud-prone zone 


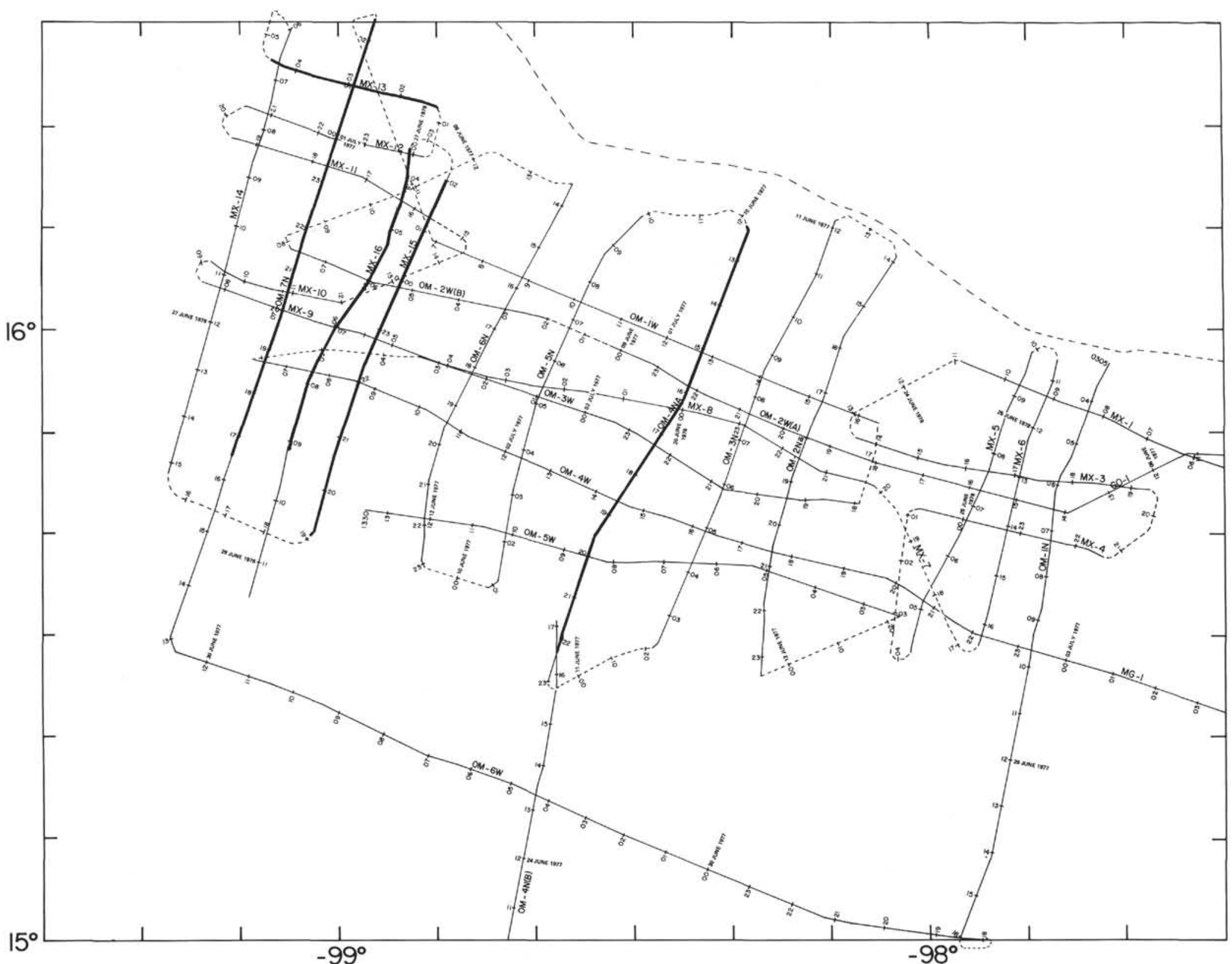

Figure 4. University of Texas multichannel track chart. Seismic sections in this paper are shown on this chart with bold line width. These sections were the data base used in Figures 10, 13, and 14 . 


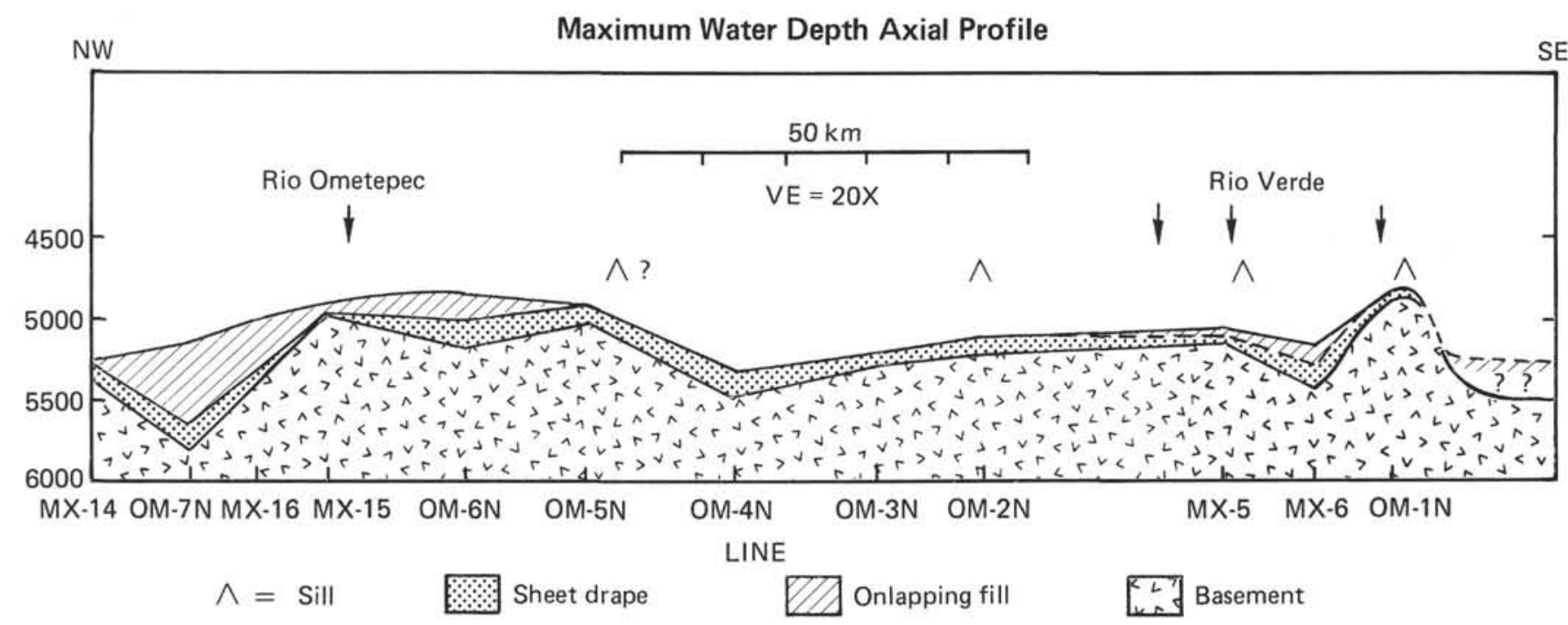

Figure 10. Axial profile of trench using the reflection sections normal to the axis for control. Note fairly smooth profile northwest of the Rio Ometepec. Sills block entry of turbidites into central portion of the axis.

elsewhere, perhaps signifying substantial differences in tectonic processes. Volumetrically, the sand within the slope sediments is extremely minor, concentrated only near submarine canyons (where Leg 66 drilling was also focused).

\section{Slope Front Fill Facies (upper slope)}

The upper slope is divided into at least two seismic facies. The slope front fill facies extends from the upper slope seaward over a portion of the moderate amplitude and continuity facies (Fig. 14). The thickness varies up to about 350 meters and has a low velocity (about 1.8 $\mathrm{km} / \mathrm{s})$. The few reflections that occur in the interval are of low amplitude and short $(<1 \mathrm{~km})$. Locally, low-amplitude reflections are observed near Site 490. Reflections near the base of this interval terminate both updip and downdip against an unconformity (labeled 2 in Figs. 15 and 16).

This facies is interpreted by Sangree and Widmier (1977) as a relatively deep-water sediment complex related to submarine fans. However, drilling recovered predominantly muds with fine silt, sand, and ash layers. Although this seismic facies is thickest and extends farther downslope in the vicinity of the two major canyon systems (Fig. 13), the origin of the sequence is not welldocumented. Deposition is principally from slow settling through the water column, with some sheet-like fine sand layers. The lack of significant internal reflections makes it difficult to characterize the internal geometry which would help identify this interval and its environmental significance. To the southeast, where the internal reflections are best developed, this facies directly onlaps continental crust (Fig. 13). This implies that this interval is a relative sea level-high stand (transgressive) deposit.

\section{Progradational Facies (upper slope)}

One facies is restricted to lows in continental basement. It occurs northwest of the Ometepec Canyon in the vicinity of Site 493 and in a low centered in $15^{\circ}$ $55^{\prime} \mathrm{N}, 98^{\circ} 15^{\prime} \mathrm{W}$ (Fig. 14). The external geometry of this interval is difficult to define because of the restricted nature of the facies and lack of a dense seismic grid. This facies contains several unconformities. The surface labeled 3 in Figures 15 and 16 separates the facies into two significant velocity packages about $2.0 \mathrm{~km} / \mathrm{s}$ over $2.3 \mathrm{~km} / \mathrm{s}$ (Shipley et al., 1980).

Reflections are variable, low and moderate amplitude, continuous over only short distances $(<2 \mathrm{~km})$. A downlapping, prograding geometry, best developed parallel to the margin, indicates filling of a basement depression from both the northwest and southeast.

Reflections are not well enough developed to distinguish between oblique and sigmoid-type geometries in order to identify this facies according to the Sangree and Widmier (1977) scheme. It is, however, clearly a progradational sequence. Both the paleobathymetric results and the mud, silty mud, and sands in this interval suggest a moderate water depth for most of the period of deposition. This suggests that deposition was largely controlled by low-velocity turbidity currents and bottom current action. The depositional pattern is higherenergy than the overlying slope front fill facies.

\section{STRUCTURE}

The seismic reflection grid reveals many details of basement topography. Using the seismic reflection data and velocity information from both sonobuoys and reflection methods, I constructed a generalized map of the basement surface (Fig. 14) which allows correlation of basement structure, bathymetry, and gross sediment geometry.

\section{Continental Crust}

The continental crust is well defined in the seismic reflection data except at its seaward termination. The ambiguity in the location of the seaward termination results from the steep dip of the contact. The dashed line in Figure 13 is the most seaward limit of the observed reflection. The top of the continental crust represents 


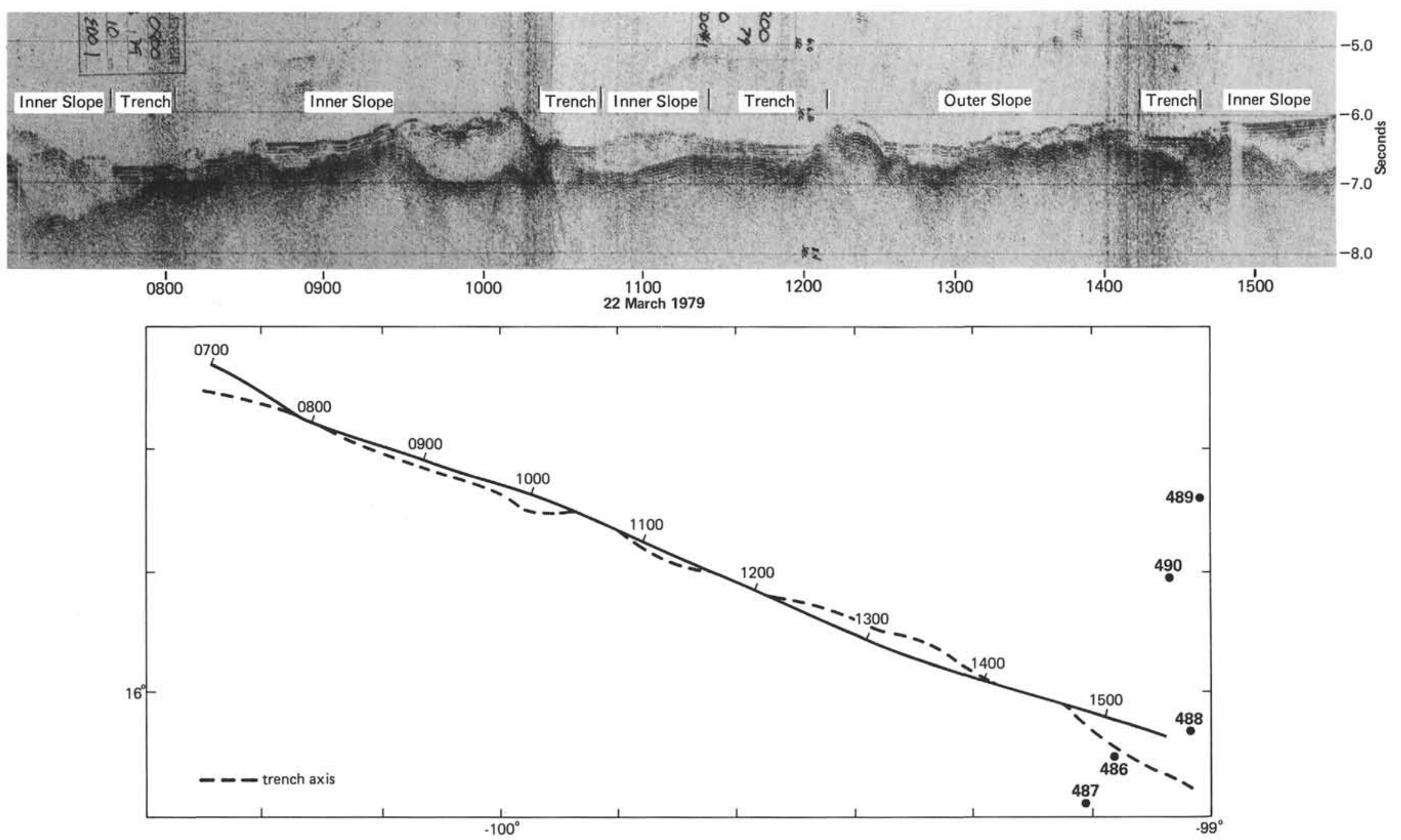

Figure 11. Glomar Challenger Leg 66 profile approaching Site 486. Trench axis ponds where identified show steady deepening to the northwest into the Acapulco deep. 


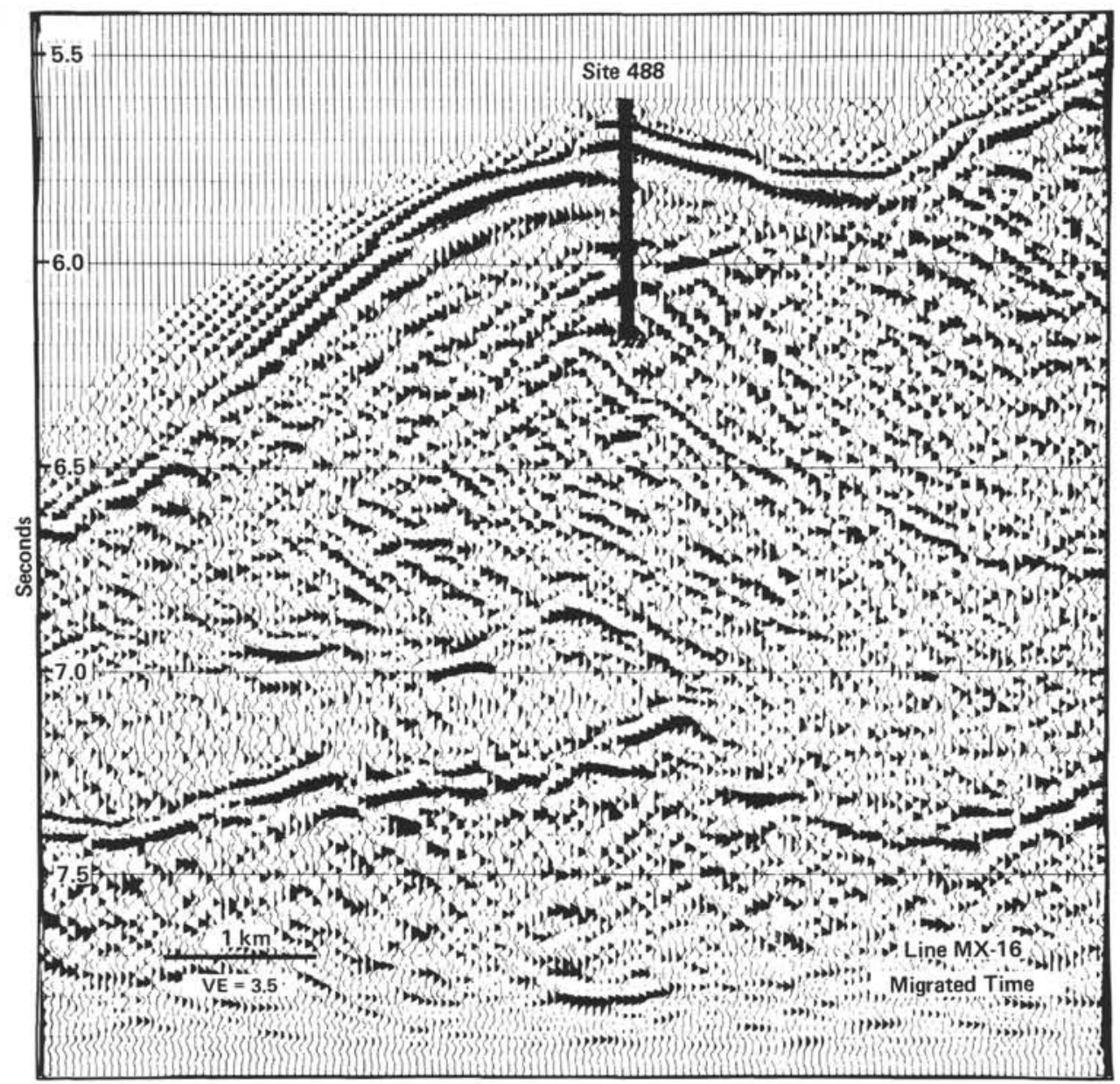

Figure 12. Detail of Line MX-16 near Site 488 showing the nature of the contact between the chaotic fill and moderate amplitude and continuity facies.

either a fairly continuous high-amplitude reflection or a reflection broken or offset on a scale of kilometers. No obvious correlation exists between observed basement velocities; details of reflections (rough vs. smooth) (Fig. 13); and samples of schist (Site 489), diorite (Site 493), and biotite gneiss (Shipley et al., 1980). The small-scale reflection disruptions are probably only indirectly related to the basement by faulting or erosional features formed during or before subsidence and renewed sedimentation in the early Miocene.

The basement topography is complex. In the northwest, near the drilling locations, the Rio Ometepec has eroded the basement rocks up to about 1000 meters (Fig. 14). The canyon appears controlled by a zone of weakness, because the channel changes direction from northnortheast to east-southeast about mid-depth. Other basins and a long ridge parallel to the channel also show that this surface had up to 1400 meters of pre-early Miocene relief. Offshore of the border between Guerrero and Oaxaca a broad, shallow platform $(<300 \mathrm{~m})$ extends seaward $25 \mathrm{~km}$ and then drops abruptly. The shelf on the eastern half of the survey area is composed of two large (20-km width) basins, both truncated on the seaward side. The Rio Verde runs offshore over one of these basins, suggesting some structural control. However, it has not substantially cut into the basement and thus the canyon may be a fairly young feature. These two truncated basins are evidence of an abrupt seaward crustal transition. They suggest substantial subsidence or actual removal of continental crust. Differential subsidence of the crust, if any, is limited to within about $10 \mathrm{~km}$ of the margin, since there is no seismic evidence that suggests shallow subsided $(<10 \mathrm{~km})$ continental crust seaward of the dashed contact. The truncation process appears to have ended about the early Miocene or earlier, since the geometry of the lower Miocene sediments shows filling of pre-existing lows.

\section{Oceanic Crust}

The oceanic crust has a maximum relief of about 1000 meters parallel to the trench (Fig. 14). The dip of the ocean plate for the $10 \mathrm{~km}$ just seaward of the trench averages $5^{\circ}$ (range $2^{\circ}-9^{\circ}$ ). The seafloor slope for the area extending $10 \mathrm{~km}$ landward of the trench is between $5^{\circ}$ and $12^{\circ}$, average $8^{\circ}$.

The dip of the oceanic crust just landward of the trench axis has been calculated and the map shown in Figure 14 compiled using an interval velocity for the slope section averaged from sonobuoy and reflection analyses of $v=1.7+0.6 T$, where $v(\mathrm{~km} / \mathrm{s})$ is the average velocity for the interval in seconds of two-way reflection time $(T)$ from the seafloor to the reflection 


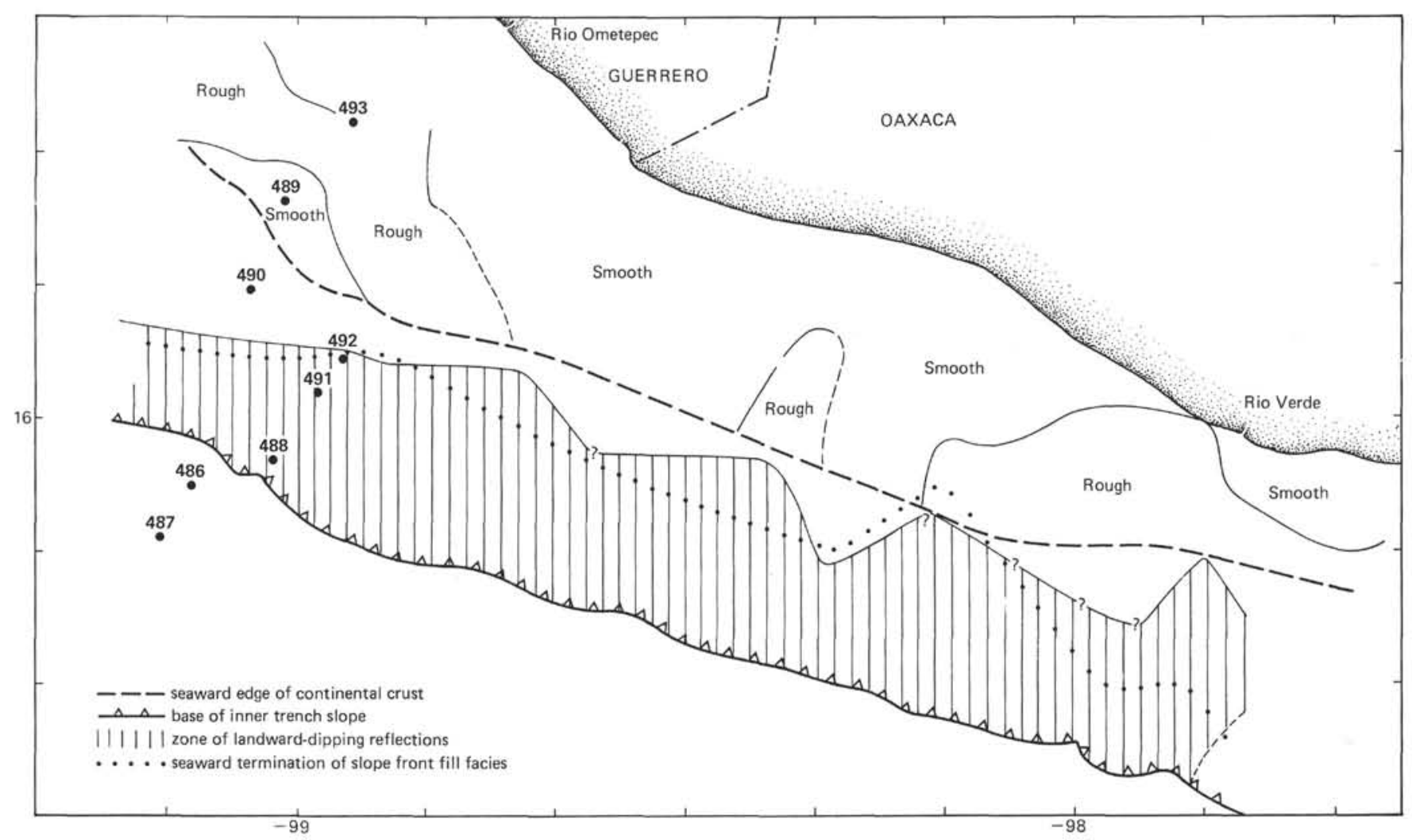

Figure 13. Chart showing distribution of slope front fill facies and moderate amplitude and continuity section.

correlated with the top of the oceanic crust. The dip calculated, which would vary systematically with a different velocity function, averages $8^{\circ}\left(\right.$ range $\left.5^{\circ}-10^{\circ}\right)$, the same as the seaward portion of the crust. The dip of the downgoing slab from refraction work (Mooney et al., 1975 ; Keller et al., 1979) is about $13^{\circ}$. Since this is larger than our near trench dip of $8^{\circ}$ and the difference is more than can be accounted for by inaccuracies in our velocity function, the dip increases shoreward.

On individual profiles there is no apparent relation between the dip of the oceaic crust and the dip of the overlying slope deposits at the base of the slope. This suggests that the variations in slope and structures of the inner wall (Fig. 1) are independent of small changes in subducting crust morphology (up to $1-\mathrm{km}$ relief along strike). The origin of these variations must be in the subduction process or variations in the sedimentary regime in time and space along the margin. I will return to this problem after a discussion of slope structures.

\section{Lower Slope Structures}

Lower slope structures of this area have been reviewed by Moore et al. (1979) and Shipley et al. (1980). Small-scale folds and thrust faults are observed only in parts of the trench axis containing the onlapping fill facies (Figs. 6 and 7). These variations are apparently unrelated to differences in the stress field, since these profiles are separated by only a few kilometers and there is no correlation between inner slope and outer slope gradients. Local changes in sedimentation accumulation rates or sediment components might explain some of the variation. The axial profile (Fig. 10) illustrates that at present, sediments of the Rio Ometepec are flowing northwestward in channelized flow to be deposited in the vicinity of Line OM-7N, particularly bypassing the trench near Line MX-16. In the vicinity of Line MX-15, the trench is probably still receiving significant fan-type sediments along the base of slope. Longer-term accumulation rates (for the last 85 to $145,000 \mathrm{y}$.) can be estimated by using the rate of subduction of $7 \mathrm{~cm} / \mathrm{y}$., the width of the axial deposits, and the thickness of the onlapping fill at the base of the slope. This longer-term rate is plotted in Fig. 17 and shows a maximum near the Ometepec Canyon mouth which decreases southeastward because of a sill(?) and northwestward as a function of the distance from the source.

The structures seem to vary systematically with the accumulation rates and sediment facies in the trench. Lines $\mathrm{OM}-4 \mathrm{~N}$ and $\mathrm{OM}-5 \mathrm{~N}$ show no axial fill and slope or slump material overlying the sheet-drape facies. No internal structures are evident (Fig. 18). Along Line OM-6N, which is also up gradient from the Rio Ometepec entry point into the trench, the section has received finer-grained components and has a trench section containing less sand and a lower accumulation rate (but still much higher than the normal sheet-drape facies). Here the deformation begins to develop more faulting and slight rotation. Perhaps the silts and clays deposited over a longer time interval are less ductile than more rapidly deposited coarse detritus. This hypothesis is supported by the observation that the sheet-drape facies beneath the base of the slope is often completely undeformed but overlain by a more highly deformed and folded section of trench turbidites. Apparently the 


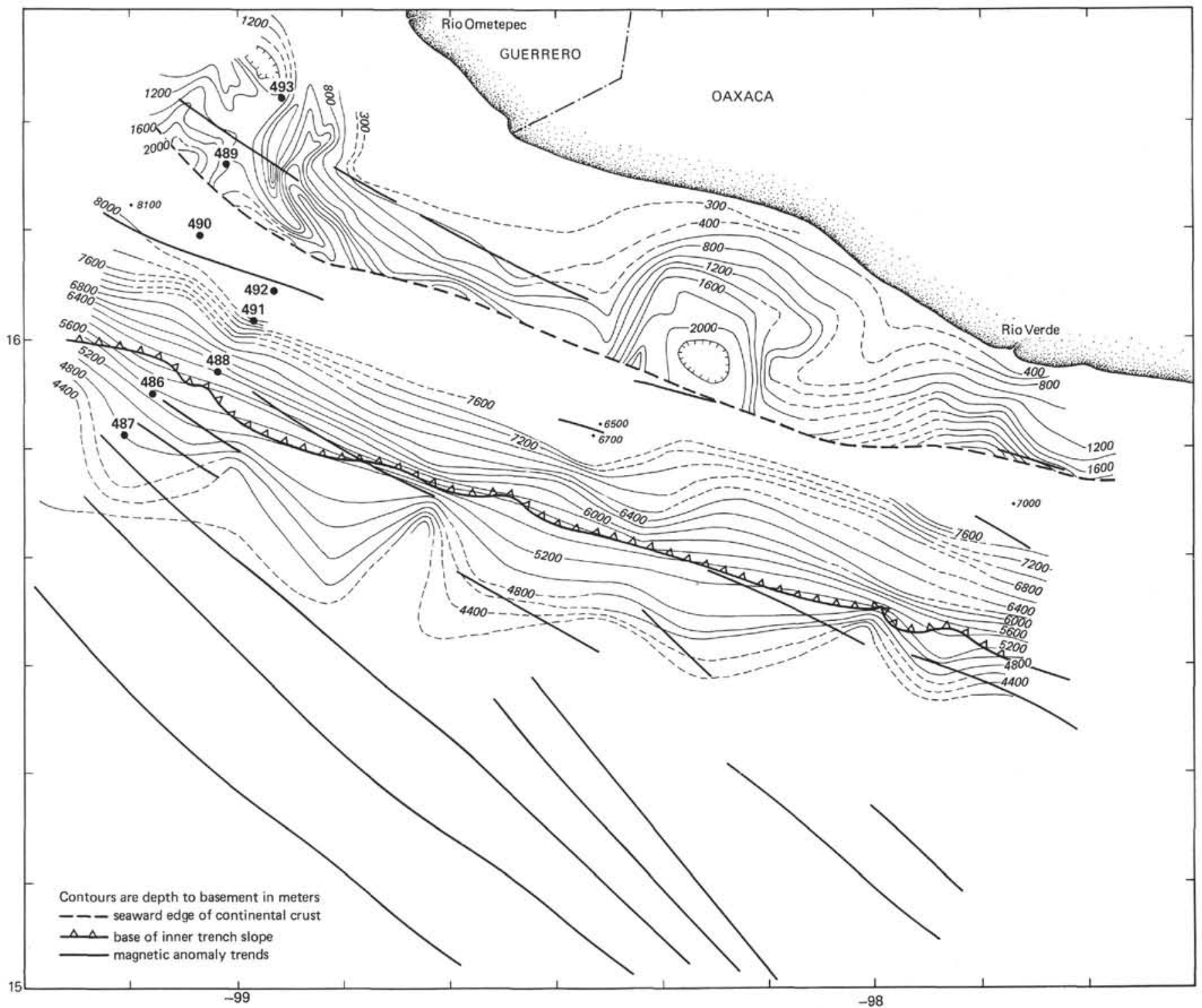

Figure 14. Depth to top of oceanic and continental crust. Continental basement trends are abruptly terminated at the seaward edge of the continent. Note the close juxtaposition of oceanic and continental crust.

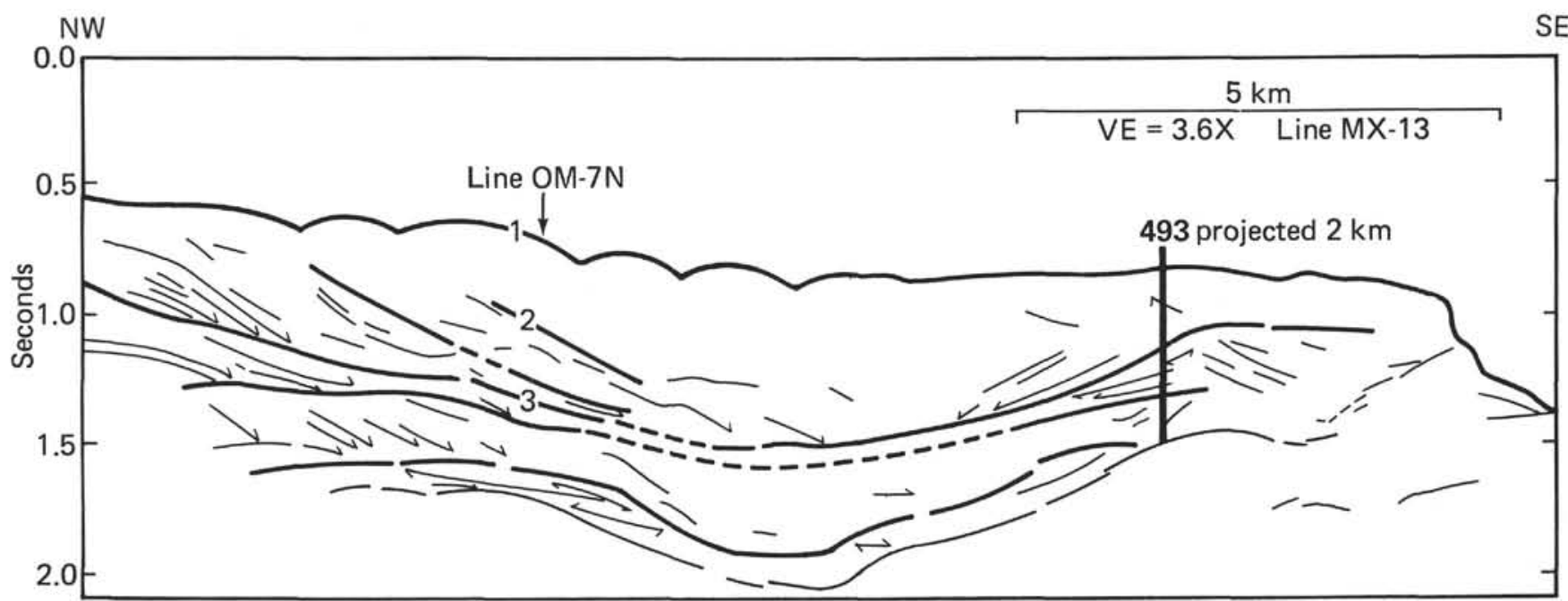

Figure 15. Line drawing interpretation of Line MX-13 near Site 493. Numbers 1 through 3 refer to major unconformities discussed in the text. 


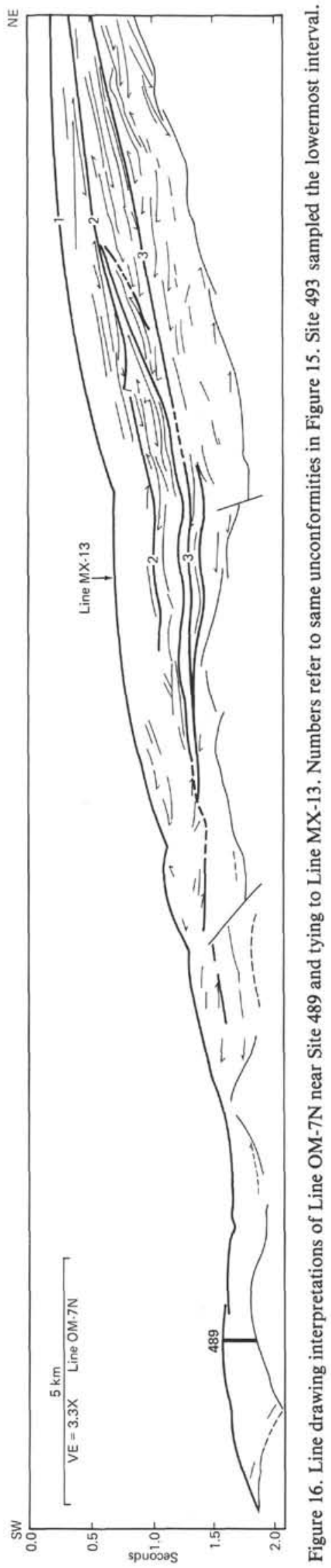

hemipelagics are not being accreted at shallow levels into the slope and behave differently in the stress field (e.g., the selective subduction model of Moore, 1975).

On Lines MX-15, MX-16, and OM-7N, fill comprises about $80 \%$ of the total sediments (at the base of slope), but the long-term accumulation rate decreases toward Line OM-7N. These sections show a progression from mainly faulting but minor folding in Line MX-15, to mainly folding in Line MX-16 with minor thrust faulting, to mainly folding in Line OM-7N. The combined factors of sediment component variation (sand vs. mud) and varying accumulation rates probably affect the response of the sediments to the same stress regime.

Although the relationship between the base of slope deformational style and sediment components/accumulation rates is speculative, there is substantial variation in the structures even within the same tectonic setting.

\section{Dipping Reflections}

The distribution of the dipping reflection interval (moderate amplitude and continuity seismic facies) was reviewed (Fig. 13) in an earlier section. On many seismic sections, shallow dips occur at the base of the slope but rapidly reach large values just upslope (e.g., Fig. 6). Dips were measured using the velocity function mentioned earlier. Although there is a large variation in apparent dip angles, low dips $\left(<8^{\circ}\right)$ are largely confined to $<4 \mathrm{~km}$ from the trench axis. Farther landward, apparent dips are variable but high. The accretion process, as displayed by the occurrence of dipping reflections, must occur near the trench, because dips soon reach a value at which further rotation is either not controlled by the distance from the tectonic front or the deformation is not primarily rotational.

\section{DISCUSSION}

The sedimentary intervals have been characterized on the basis of seismic reflection response and drilling results, but their lateral distribution and interrelations are also important (Fig. 3). Figure 13 shows the distribution of the slope front fill and moderate amplitude and continuity seismic facies. The zone of dipping reflections, although most pronounced within the slope in the northwest part of the area near the Rio Ometepec, occurs all along the slope and in places right up to the presumed seaward edge of the continental crust. Although neither the continental edge nor dipping reflections are well-defined zones, an abrupt contact between the accretionary zone and continental crust is suggested. If a transition zone exists, it is on the order of $10 \mathrm{~km}$ in width.

Overlying the ocean/continent boundary is the slope front fill facies, which pinches out downslope. This pinchout does not occur at a particular depth and is not related to erosion. Instead, it is related to mechanisms that transport the sediments seaward and to the proximity of source areas. For example, the apron extends farther seaward in the vicinity of the Rio Verde and Rio Ometepec. The dependence of this slope apron on sediment supply does not allow us to use thickness or lateral 


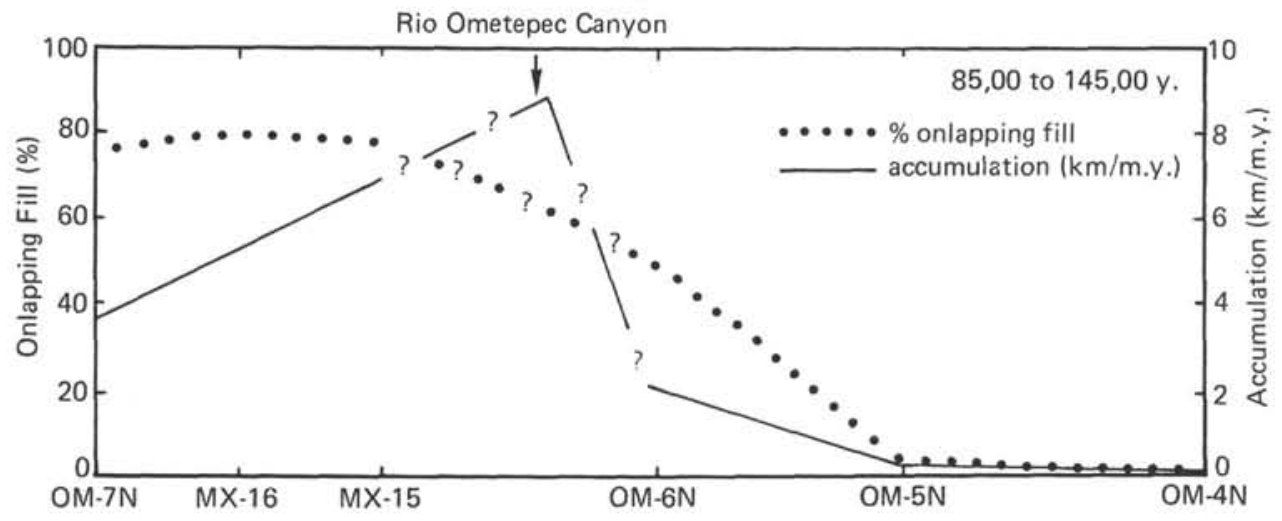

Figure 17. Estimate of long-term sediment accumulation rates in the trench axis. Data based on sediment thickness at base of inner slope and time calculated from the width of the ponded sediments using 7 $\mathrm{cm} / \mathrm{y}$. as the convergence rate. Although overly simple, the method does reveal the major features of accumulation averaged over the last 85,000 to 145,000 years (depending on trench width). Relative portions of onlapping turbidite fill and oceanic hemipelagic sediments are estimates from the seismic character.

distribution as an indication of variations in the age of the sediments producing the dipping reflections.

The moderate amplitude and continuity facies is overlain by the slope front fill facies and chaotic fill facies. The moderate amplitude and continuity facies is probably composed of onlapping fill facies and chaotic fill facies sediments tectonically incorporated into the lower slope. The chaotic fill facies is composed mainly of slumped material derived from tectonic oversteepening of the slope and hemipelagic deposits (such as the sheet drape facies), which tend to smooth the slope and fill in irregularities, particularly small discontinuous basins found on the lower slope. The oversteepening also causes slumping of the slope front fill, which in turn becomes part of the chaotic fill. The fairly abrupt seaward limit of the slope front fill is controlled by the relative rates of slope front fill sedimentation and the deformation of the upper slope. In a crude manner it is a measure of the limit of tectonic steepening of the upper slope.

The present relative plate motions are known (Minster and Jordan, 1978), but Neogene motions are poorly known for this region (Schilt and Truchan 1976). The pre-Miocene spreading history is lost, because Miocene oceanic floor is presently being subducted beneath the continent, although Cretaceous batholiths and Paleocene to Recent volcanics suggest that subduction has continued periodically, at least since the Cretaceous. The age of the truncation of this margin is known only to be post-Cretaceous and pre-early Miocene. Lower Miocene sediments are preserved only in structural lows on the continental crust.

The lack of forearc basin deposits in this part of Mexico could result from oblique subduction, pure strikeslip movement, or perhaps simply the lack of forearc development. Enough time has probably elapsed since the Miocene for the formation of a sedimentary basin. Taking the view of Dickinson and Seely (1979) and Seely (1979), this margin may not have developed a basin because of the pre-late Miocene plate configuration. Since the Miocene, subduction northwest of the Tehuantepec
Ridge may have been close to the continent with no oceanic crust or transitional crust trapped between the original suture and the continent. Perhaps as part of the pre-early Miocene event, western Mexico moved westward relative to Guatemala along the North American/ Caribbean Plate boundary.

On the Mexican margin near the Ometepec Canyon primary deformation of the sedimentary deposits occurs at the base of slope and trench region with faulting and folding occurring well out into the trench axis fill (Shipley et al., 1980). Similar deformation has been reported in the Andaman-Nicobar Ridge (Curray and Moore, 1974), the Shikoku Trench (Moore and Karig, 1976), Aleutian Trench (Seely, 1977; von Huene, 1979), Oregon-Washington margin (Silver, 1972; Carson, 1977), Sunda Trench (Moore and Curray, 1980), and elsewhere. In Mexico, the deformation front extends in places out into the trench fill up to about $5 \mathrm{~km}$, and sediments are deformed and rotated to steep dips within $4 \mathrm{~km}$ of the base of slope. Later deformation may be along pre-existing zones deeper in the section or related mainly to uplift. The drilling data (Lundberg and Moore, this volume) clearly show that deformation continues in the overlying chaotic fill facies for a considerable period after initial emplacement and rotation. However, this late stage deformation, which must be synchronous with uplift of the margin, appears to be at a fine scale. The apparent variations observed in base of slope and axial sediments (e.g., Shipley et al., 1980) are related more to local sedimentation patterns. Four seismic lines show significant variations in amounts of deformation and types of faulting and folding at the base of slope. These variations result from changes in the sediment thickness, competency of the sediments (related to lateral changes in mud/sand ratio), and original structural weakness in the oceanic plate (particularly in the case of normal faults reactivated as reverse faults).

If we consider the Guatemala (von Huene et al., 1980) or Japan Trench drilling results (Langseth, Okada, et al., 1978; von Huene, Nasu, et al., 1978), there is apparently evidence that accretion at the base of slope may 

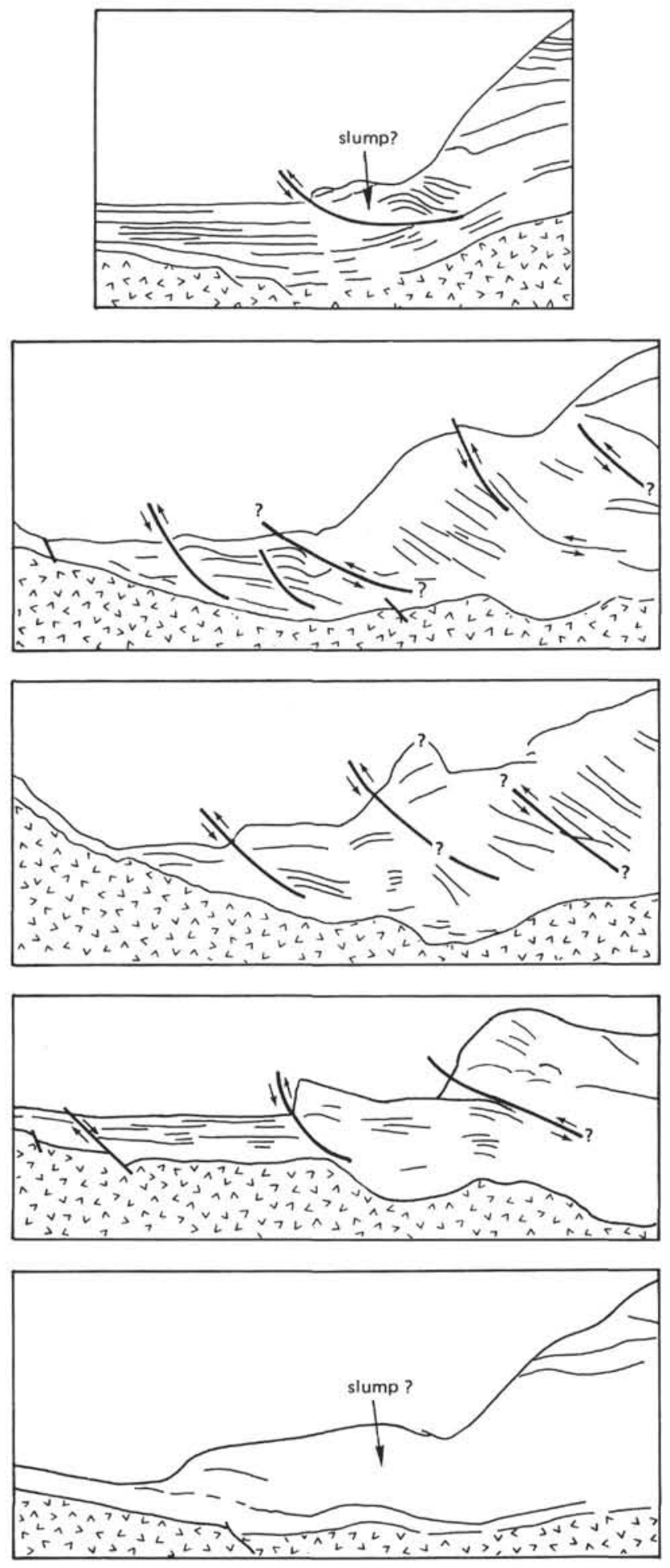
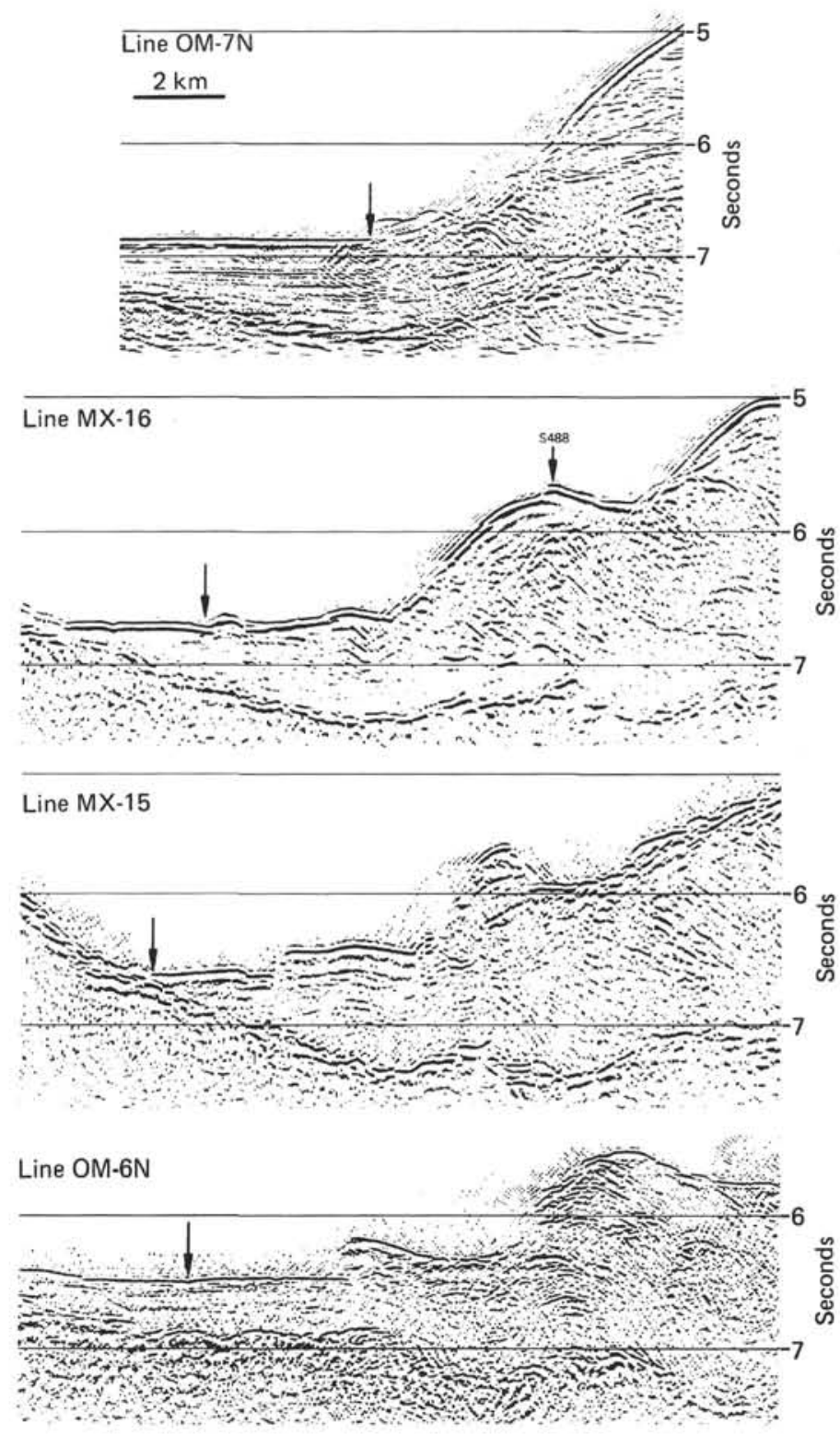

Line $\mathrm{OM}-4 \mathrm{~N}$

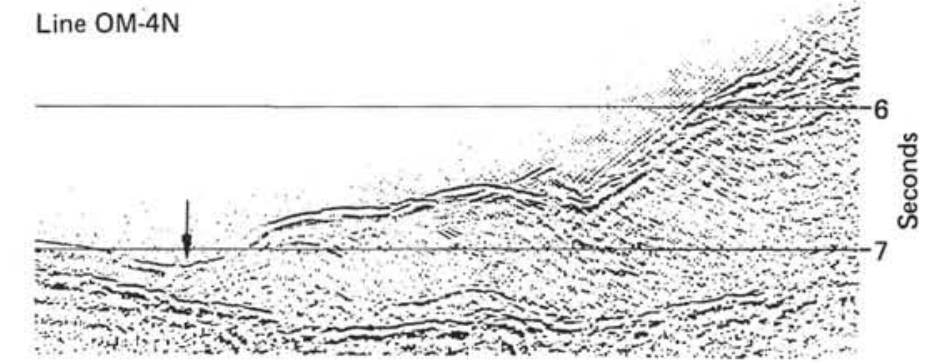

Figure 18. Wave-equation migrated seismic sections at the base of slope near the Ometepec Canyon. Compare variations in deformation style accumulation rates and sediment components in Figure 17.

be slow, episodic, or completely lacking. The seismic profiles just south of the Mexico DSDP transect (southeast of Line OM-6N) are interpreted in a similar manner to the Guatemalan transect. No discrete lower slope structures are observed. The absence of lower slope reflections can be interpreted as either a lack of impedance contrast in bedding and faults or structures too complex to be resolved by the geophysical methods. Off Guatemala there is no significant accumulation of sandy trench turbidites, and turbidites amount to less than one-half of the total trench section near the San Jose Canyon and even less to the north or south (von Huene et al., 1980; McMillen, in press). Off Mexico, where slope structures are defined by reflections, turbidite ac- 
cumulation rates are higher and the proportion of turbidites to hemipelagics is greater than $60 \%$ (Fig. 17). Thus the preferred interpretation is that where there are no base of slope reflections, there are no structures to resolve regardless of impedance contrasts.

Moore (1975) has noted that trench turbidite sediments are preferentially incorporated into the base of slope with underlying oceanic and hemipelagic sediments continuing reasonably undisturbed deeper into the section. This observation is supported by Scholl and Marlow (1974), who have noted that in exposed melanges pelagic deposits are rare. Continuation of the hemipelagic deposits beneath the lower slope is observed along the Middle America Trench (Shipley et al., in press) and elsewhere (Karig and Sharman, 1975; Kulm and Fowler, 1974; Moore and Curray, 1980; von Huene, 1979). A corollary of this observation is that no significant accretion or outbuilding at the base of slope occurs if turbidites are not present. However, because we have significant growth and uplift of the accretionary zones even in areas with insignificant turbidites, accretion must continue at a deeper structural level by a different process. The question of erosion or steadystate base of slope features, as off Guatemala, remains an area requiring further investigation.

The lower slope deformation near the Rio Ometepec confirms that growth of the slope does occur by addition of sediments in some lower slope regions but does not adequately explain the volume or regional uplift, since most rotation occurs in the lowermost slope. Understuffing at the base of slope could cause the observed uplift, but the dips in the slope should increase upslope. Thus these data suggest that other tectonic processes in deeper parts of the accretionary zone underplate sediments that are responsible for the regional uplift and significant growth of the margin in areas with few trench turbidites.

\section{ACKNOWLEDGMENTS}

This project was conducted while I was at the University of Texas Marine Science Institute in Galveston, Texas. The high-quality seismic reflection data attest to the ability and effort of the marine geophysical group in Galveston, including K. Griffiths, J. Kunselman, and A. Roberts. Discussions with colleagues at the University of Texas and at Scripps Institution of Oceanography and with participants in the Leg 66 drilling program helped form the ideas expressed in this report. It was improved by the reviews of J. Austin and G. Moore. The investigation was supported by the Oceanography Section of the National Science Foundation Grant OCE-76-2330 and NSF-IPOD subcontracts through Columbia University CU-TEX 25907-2-3.

\section{REFERENCES}

Carson, B., 1977. Tectonically induced deformation of deep-sea sediments off Washington and northern Oregon: Mechanical consolidation. Mar. Geol., 24:289-307.

Curray, J. R., and Moore, D. G., 1974. Sedimentary and tectonic processes in the Bengal deep-sea fan and geosyncline. In Burk, C. A., and Drake, C. L. (Eds.), The Geology of Continental Margins: New York (Springer-Verlag), pp. 617-627.

Damuth, J. E., and Embley, R. W., 1979. Upslope flow of turbidity currents on the northwest flank of the Ceara Rise: Western Equatorial Atlantic. Sedimentology, 26:825-834.

de Czerna, Z., 1971. Precambrian sedimentation, tectonics and magmatism in Mexico. Geol. Rundsch., 60:1488-1511.

Dickinson, W. R., and Seely, D. R., 1979. Structure and stratigraphy of forearc regions. Am. Assoc. Petrol. Geol. Bull., 63:2-31.
Fisher, R. L., 1961. Middle America Trench: Topography and structure. Geol. Soc. Am. Bull., 72:703-720.

1974. Pacific-type continental margins. In Burk, C. A., and Drake, C. L. (Eds.), The Geology of Continental Margins: New York (Springer-Verlag), pp. 25-44.

Guzman, E. J., 1950. Geologia del noreste de Guerrero. Bol. Asoc. Mex. Geol. Pet., 2:95-156.

Hussong, D. M., Edwards, P. B., Johnson, S. H., et al., 1976. Crustal structure of the Peru-Chile Trench: $8^{\circ} \mathrm{S}-12^{\circ} \mathrm{S}$ latitude. In Sutton, G. H., Manghnani, M. H., and Moberly, R. (Eds.), The Geophysics of the Pacific Ocean Basin and its Margin: American Geophysical Union, Geophysical Monograph 19:71-86.

Karig, D. E., 1974. Tectonic erosion of trenches. Earth Plan. Sci. Lett., 21:209-212.

Karig, D. E., Cardwell, R. K., Moore, G. F., et al., 1978. Late Cenozoic, subduction and continental margin truncation along the northern Middle America Trench. Geol. Soc. Am. Bull., 89: 265-276.

Karig, D. E., and Sharman, G. F., 1975. Subduction and accretion in trenches. Geol. Soc. Am. Bull., 86:377-389.

Keller, B., Lewis, B. T. R., Meeder, C., et al., 1979. Explosion seismology studies of active and passive continental margins. Am. Assoc. Petrol. Geol. Mem., 29:443-451.

Kesler, S. E., 1973. Basement rock structural trends in southern Mexico. Geol. Soc. Am. Bull., 84:1059-1064.

Kulm, L. D., and Fowler, G. A., 1974. Oregon continental margin structure and stratigraphy: A test of the imbricate thrust model. In Burk, C. A., and Drake, C. L. (Eds.), The Geology of Continental Margins: New York (Springer-Verlag), pp. 261-283.

Langseth, M., Okada, H., Adelseck, C., et al., 1978. Near the Japan Trench transects begun. Geotimes, 22:22-26.

McMillen, K. J., in press. San Jose Submarine Canyon, Middle America Trench, Guatemala: Its influence on slope and trench sedimentation, and tectonic accretion. Mar. Geol.

McMillen, K. J., Enkeboll, R. H., Moore, J. C., et al., in press. Sedimentation in different environments of the Middle America Trench, southern Mexico and Guatemala. In Leggett, J. (Ed.), Trench and Forearc Sedimentation and Tectonics in Modern and Ancient Subduction Zones: Geol. Soc. London.

Minster, J. B., and Jordon, T. H., 1978. Present-day plate motions. J. Geophys. Res., 83:5331-5354.

Mitchum, R. M., Vail, P. R., and Sangree, J. B., 1977. Stratigraphic interpretation of seismic reflection patterns in depositional sequences. Am. Assoc. Petrol. Geol. Mem., 26:117-133.

Mooney, W. M., Meyer, R. P., Helsley, C. E., et al., 1975. Refracted waves across a leading edge: Observations of Pacific shots in southern Mexico. Trans. Am. Geophys. Union., 56:452.

Moore, G. F., and Curray, J. R., 1980. Structure of the Sunda Trench lower slope off Sumatra from multichannel seismic reflection data. Mar. Geol. Res., 4:319-340.

Moore, G. F., and Karig, D. E., 1976. Development of sedimentary basins on the lower trench slope. Geology, 4:693-697.

Moore, J. C., 1975. Selective subduction. Geology, 3:530-532.

Moore, J. C., Watkins, J. S., Shipley, T. H., et al., 1979. Progressive accretion in the Middle America Trench, southern Mexico. Nature, 281:638-642.

Piper, D. J. W., 1973. The sedimentology of silt turbidites from the Gulf of Alaska. In Kulm, L. D., von Huene, R., et al., Init. Repts. DSDP, 18: Washington (U.S. Govt. Printing Office), 847-867.

Ross, D. A., and Shor, G. G., 1965. Reflection profiles across the Middle America Trench. J. Geophys. Res., 70:5551-5572.

Sangree, J. B., and Widmier, J. M., 1977. Seismic interpretation of clastic depositional facies. Am. Assoc. Petrol. Geol. Mem., 26: 165-184.

Schilt, F. S., and Truchan, M., 1976. Plate motions in the northern part of the Cocos Plate. Trans. Am. Geophys. Union, 57:333.

Scholl, D. W., Christinsen, M. N., von Huene, R., et al., 1970. PeruChile Trench, sediments and sea-floor spreading. Geol. Soc. Am. Bull., 81:1339-1360.

Scholl, D. W., and Marlow, M. S., 1974. Sedimentary sequences in modern Pacific trenches and the deformed circum-Pacific eugeosyncline. In Dott, R. H., and Shaver, R. H. (Eds.), Modern and Ancient Geosynclinal Sedimentation: Soc. Econ. Paleo. Min. Spec. Pub., 19:193-211. 
Seely, D. R., 1977. The significance of landward vergence and oblique structural trends on trench inner slopes. In Talwani, M., and Pittman, W. C. (Eds.), Island Arcs, Deep-Sea Trenches, and BackArc Basins: Washington (American Geophysical Union), pp. 187-198.

1979. The evolution of structural highs bordering major forearc basins. Am. Assoc. Petrol. Geol., 29:245-260.

Seely, D. R., Vail, P. R., and Walton, G. F., 1974. Trench slope model. In Burk, C. A., and Drake, C. L. (Eds.), The Geology of Continental Margins: New York (Springer-Verlag), pp. 249-260.

Shipley, T. H., 1978. Sedimentation and echo characteristics in the abyssal hills of the west-central North Atlantic. Geol. Soc. Am. Bull., 89:397-408.

Shipley, T. H., Ladd, J. W., Buffler, R. T., et al., in press. Tectonic processes along the Middle America Trench, inner slope. In Leggett, J. (Ed.), Trench and Forearc Sedimentation and Tectonics in Modern and Ancient Subduction Zones: London (Geological Society of London).
Shipley, T. H., McMillen, K. J., Watkins, J. S., et al., 1980. Continental margin and lower slope structures of the Middle America Trench near Acapulco, Mexico. Mar. Geol., 35:65-82.

Silver, E. A., 1972. Pleistocene tectonic accretion of the continental slope off Washington. Mar. Geol., 13:239-249.

Underwood, M. B., and Karig, D. E., 1980. Role of submarine canyons in trench and trench-slope sedimentation. Geology, 8:432436.

von Huene, R., 1979. Structure of the outer convergent margin off Kodiak Island, Alaska, from multichannel seismic records. Mem. Am. Assoc. Petrol. Geol., 29:261-290.

von Huene, R., Aubouin, J., Azema, J., et al., 1980. Leg 67: The Deep Sea Drilling Project Mid-America Trench transect off Guatemala. Geol. Soc. Am. Bull., 91:421-432.

von Huene, R., Nasu, N., et al., 1978. Japan Trench transected. Geotimes, 22:16-21. 